\title{
A Common Threat Analysis of Intergovernmental Policy Convergence in the Framework of Regional Integration: A Case Study of the ASEAN Strategic Partnership "Our Eyes"
}

\section{Fachruddin Usuluddin}

Department of Total War Strategy, Universitas Pertahanan, Bogor, Indonesia fachruddinusuluddin@gmail.com

\section{Pujo Widodo}

Department of Total War Strategy, Universitas Pertahanan, Bogor, Indonesia pujowidodo78@gmail.com

\section{Barik Ali Amiruddin}

Universitas Indonesia, Depok, Indonesia

aliamiruddin.baa@gmail.com

Submitted: 6 May 2019; Revised: 10 November 2019; Accepted: 24 February 2020

\begin{abstract}
Abstrak
Semenjak tahun 2016, terjadi peningkatan yang cukup signifikan terkait peristiwa serangan teroris di beberapa negara anggota ASEAN. Merespon hal tersebut, Indonesia menginisiasi pembentukan kerjasama pertukaran informasi intelijen dengan nama Our Eyes Initiative (OEI) ke beberapa negara anggota serta mengkomunikasikan bahwa jaringan teroris transnasional adalah suatu ancaman bersama. Sebagian kalangan optimis bahwa dalam kerjasama ini akan menghasilkan integrasi regional yang efektif, sebagian yang lain skeptis bahwa kondisi kawasan masih diwarnai kompetisi ekonomi, pertahanan serta dominasi negara-negara seperti China dan Amerika sehingga berpengaruh pada kerjasama tersebut. Penelitian ini bertujuan untuk menganalisis bagaimana transnational terrorism mendorong negara anggota ASEAN menggunakan mekanisme transnational communication Holzinger dan Knill dalam kerisama OEl. Penelitian ini merupakan bagian dari kajian hubungan internasional sehingga peneliti menjadikan paradigma tradisional realis/neorealis sebagai dasar dalam menjelaskan kondisi regional. Penelitian menggunakan metode kualitatif eksplanatif. Pengumpulan data didapatkan melalui sumber sekunder serta dianalisis dengan cara komparasi data, verifikasi, dan penarikan kesimpulan. Sejauh ini, kajian cross-national convergence sampai pada sebuah temuan bahwa konvergensi antar negara hadir akibat pengaruh dari institusi regional sehingga menciptakan produk kebijakan yang diadopsi masing-masing negara. Namun, penulis berargumen bahwa dalam studi kasus kerjasama OEI konvergensi terlebih dahulu dipengaruhi oleh suatu common threat sehingga suatu negara merespon dan menciptakan mekanisme transnational communication.
\end{abstract}

Kata Kunci: realism, neorealisme, regionalisme, integrasi regional, komunikasi transnasional, ASEAN Our Eyes.

\begin{abstract}
Since 2016, there has been a significant increase in the incidence of terrorist attacks in several ASEAN Member States (AMS). In response, Indonesia initiated the formation of an intelligence information exchange cooperation namely Our Eyes Initiative (OEI) to several AMS and communicated that the transnational terrorist network is a common threat. Some are optimistic, this cooperation will result an effective regional integration, while others are sceptical that the condition of the region is still tinged with economic, defence competition and super power states dominance such as China and America so that it affects the cooperation. This study aims to analyze how transnational terrorism encourages AMS to use the transnational communication mechanism from Holzinger and Knill in the OEI cooperation. This research is a part of International Relations studies so that researchers make the traditional realist/neorealist paradigm as a basis in explaining regional conditions. The study use qualitative explanative method. Data collection were obtained through secondary sources and analyzed by means of data comparison, verification and conclusion drawing. So far, the cross-national convergence study has come to the finding that convergence among countries is present due to the influence of regional institution so as to create policy product adopted by each state. However, the authors argue that in the OEI case study is primarily influenced by a common threat so that the state responds and creates a transnational communication mechanism Keywords: realism, neorealism, regionalism, regional integration, transnational communication, ASEAN Our Eyes.
\end{abstract}




\section{INTRODUCTION}

The case of ASEAN Our Eyes (AOE) has only been specifically examined in the approach of international cooperation by considering at the opportunity and optimization aspects of counter-terrorism cooperation in the Southeast Asia region (Wulolo \& Legionosuko, 2019). Although this case has not been widely studied in the academic realm, several studies have made the AOE case a sub-discussion in the study of combating terrorism which still focuses on the approach of international cooperation (Sutrimo, 2018; Gunaratna, 2018). From the literature, the researchers discover that $\mathrm{AOE}$ is directly concluded as a prospective regional policy product so that it is projected to undergo gradation in both quality and quantity. The researchers believe that the approach used reflects the study of regionalism as seen from the state-centric liberal/neoliberal approach. ${ }^{1}$ Whereas empirically, besides the formation of the AOE amid political, security and competitive economic instability, the presence of a common threat (transnational terrorism) is a core cause that encourages countries in ASEAN to rationally employ the transnational communication mechanism within the framework of regional integration. Therefore, this reason underlies the researchers to use the realist/neorealist approach in the study of regionalism. ${ }^{2}$

At the beginning of its initiation, Our Eyes Initiative (OEI) was signed by six ASEAN Ministers of Defense as cooperation in exchanging intelligence information in combating terrorism. This cooperation was claimed as Indonesia's initiative in responding to the rise of the terrorist threat in each AMS. Thus, it indirectly caused the Southeast Asia region to become less conducive. ${ }^{3}$ This cooperation process was gradually followed by all AMS so that it was transformed into ASEAN Our Eyes (AOE). From the case above there is a cross-national convergence mechanism which is in the study of Holzinger and Knill (2005) and Holzinger, et al. (2008) define that the existence of a convergence policy among AMS is a change process of cause and effect from time to time in regional political conditions, policy instruments, international organizations, and so forth.
Nevertheless, in the discussion of cause and effect, Holzinger and Knill (2005) acknowledge that they still find deficiencies in finding empirical evidence of causal policies for intergovernmental convergence. However, there is research that has contributed to this deficiency by finding that the influence of regional institutions is a major contributing factor to the convergence of policies among countries in ASEAN in the case of the ASEAN Open Skies (Azali, 2017). He stated that each of the states joined in ASEAN Open Skies adopted an agreed policy due to the influence of the characteristics of ASEAN regionalism. However, in this study, the researchers found a causal difference in the OEI collaboration case study. The researchers believe that the OEI formation is not caused by direct influence from regional institutions, but is preceded by the force of shared threats so that rationally each AMS carries out a transnational communication mechanism within the framework of regional integration.

Furthermore, regional conditions in Southeast Asia in terms of politics and security still have intra-regional problems such as border disputes (territorial disputes), trans-boundary crime, and so forth. Besides, the presence of economic and military dominance of China also affects to the economic competition in the region. In the actual fact, the term of intelligence information exchange in efforts to counter terrorism, similar to the AOE's main purpose is not really new. Since the issue of transnational crimes occurred in ASEAN, this regional organization had formed several exclusive associations as well as agreements on exchanging intelligence information which were convened at successive high-level meetings. However, the outcomes of those efforts were relatively failed and ineffective to deal with such a matter (transnational crime), these failures could be seen from many acts of transnational terrorism in the region that could not be solved directly. This indicates that the initiations only from ASEAN framework are proved unsuccessful. However, in the case of OEI, although it has the same persistence as previous program, what could be differentiated is the effort was struggled by one of ASEAN Member States. In addition, the term OEI as an intelligence exchange information cooperation was found not only in Southeast Asia, because during World War II, there was a similar 
association called Five Eyes intelligence collaboration. ${ }^{4}$ In this case, Gunaratna (2018) states that the initiation of the OE was an imitation of the Five Eyes program model. Based on the problems explained, the following part describes the theoretical-conceptual framework and research methods used within the study.

Moreover, the researchers also discuss why the OEI program content remains the same as the previous collaboration, and why the previous collaboration did not run effectively. In the next part, the researchers identify whether or not this OEI policy program is an imitation of the Five Eyes intelligence collaboration concept. Finally, a conclusion is presented on whether or not the collaboration is effective and long-term.

\section{THEORETICAL FRAMEWORK}

There is a deficit in determining causal factors for intergovernmental policy convergence explicitly. One of which is caused by heterogeneity in the study of intergovernmental policy convergence studies that academics from different disciplines such as political comparison, policy analysis, and international relations study them (Holzinger \& Knill, 2005). As an empirical example from this research, that tends to come from the field of international relations studies, is related to the analysis of a policy within the framework of regional cooperation of AOE. Therefore, the initial approach used in this research is the traditional perspective of the field of international relations studies, namely realist/neorealist. It consistently makes state-centric/state-centered as a rational analysis center in seeing an anarchist global political constellation and its pessimistic views related to international cooperation. In the study of policy convergence among states, matters relating to the state as an autonomous agent are also discussed by Bennett (1991) by mentioning that policy convergence is influenced by an external penetration outside the state so that it is required to carry out a policy.

In addition, because the policy analysis that occurred was within the framework of regionalism, the researchers used the concept of regional integration in the realist/neorealist approach which was used as the fundamental paradigm. More specifically, this study of regionalism used a more traditional wave theory in a realist/neorealist intergovernmental approach, and there is an argument supporting this case. Wunderlich (2007) stated that the realist/neorealist has analyzed ASEAN by stating that economic dependence, which is often claimed as the initial foundation in regional cooperation in ASEAN by liberal/neoliberal within the framework of international cooperation and integration, does not happen, and what correctly arises are the unstable politic and economic competition by which those have the potency to cause conflicts among AMS. Jurgen Ruland also conveys in Wunderlich (2007) that until the 21st century, ASEAN would still be a period of realism. Tsuyoshi Kawasaki, who argues that ASEAN as a regional organization that builds confidence-building measures (CBMs) in its core program, is essentially an effort to serve the interests of member states. Therefore analysis through a realist lens is needed (Acharya \& Stubbs, 2006).

In seeing the international political contestation in ASEAN in the 21st century with the presence of the influence of two major powers namely China and US in its dominance related to security and economic issues, the researchers utilized five core premises of the realist/neorealist Gerstl and Strasakova (2017). First, the state is a central actor in the international system, which is characterized by anarchy conditions (the absence of the highest order). Second, relations among countries in a network are characterized by a distrust of shared intentions. Third, the state must act on the principle of "self-help" with the primary objective being to secure its survival. Fourth, conflict and war are permanent features in the international system. Fifth, the cause of the battle is the imbalance power among countries in the global order. Consequently, in the above conditions there are three basic strategies of nations as an effort to maintain their survival, namely balancing, bandwagoning, and buck-passing.

In the context of interaction among countries in an international anarchist environment, realism believes that power is the primary condition for survival so that the interaction that arises is a balance of power as a basis for seeking security and creating order and stability in 
international politics (equilibrium theory) (Stein, 2015). The realist view related to international cooperation in dealing with shared threats is a temporal thing which is based on the argument that the continuity of such agreement only exists when a common threat arises or is a matter of mutual interest (Stein, 2001; Wunderlich, 2007). Griecon (1996; 1997) and Kim (2011) in Wunderlich (2007) explain that the process of regional integration can be seen from the capabilities of a country, if there is relative stability in terms of capabilities among countries in the region, it will lead to sincere cooperation in a formal framework. On the contrary, if it does not happen, a weak state will worry about a stronger nation.

The discussion related to the theory of intergovernmental policy convergence from Holzinger \& Knill (2005) offers five kinds of causal mechanisms that influence policy convergence. First, imposition, which refers to the convergence that occurs when external political actors force a government to adopt specific policies. Second, international harmonization, it is when the countries involved have legal obligations as members of international institutions to take specific policies and programs. Third, regulatory competition, which is the convergence of systems that arise as a result of pressure on a country's policies from new policies adopted by most states that a state must adjust these new policies to avoid obstacles in a competition. Fourth, transnational communication, which is related to the convergence caused by the transnational communication mechanism. Holzinger \& Knill (2005) divide it into four different but related mechanisms because the four mechanisms are based on communication among countries, namely lesson-drawing, transnational problem-solving, emulation, and transnational promotion of policy models (see figure 1). (i) Lesson-drawing, there are several opinions related to the pattern of mechanisms that occur specifically as a rational agent, state A voluntarily learns from state B in terms of solutions to share problems in which it can be positive or negative lessons. According to Meseguer in (Holzinger \& Knill, 2005), these countries will have alignment in policies if they hold the same information, however, if each state has different information, it results in a divergence. (ii) Transnational problem-solving has similarities with lesson-drawing. However, the resulting convergence is a factor of development related to the perception of shared problems and solutions associated with the likeness of domestic issues. According to Haas in Holzinger \& Knill (2005), a characteristic of the transnational problem-solving mechanism is where it occurs in transnational elite networks, that is when the elite transnational network shares information related to goals and ways in trying new knowledge in dealing with joint problems. (iii) Emulation of policies is the emulation mechanism that encourages convergence which is interpreted as a desire in terms of compatibility with other countries rather than the search for practical solutions to a problem. In this mechanism, there are several explanations from academics, one of them is Benneth (1991) in Holzinger and Knill (2005) who mentions that emulation is a consequence of time pressure: 'the more urgency is felt, the more likely it is to imitate a solution without conduct lengthy analysis and investigation'. (iv) International policy promotion, which is in contrast to the transnational problem-solving mechanism that is present due to the efforts of countries or representations of transnational networks in discussing common problems regarding the provision of solutions, is driven by the active role of international institutions that promote approaches explicitly promised. In this mechanism there is no binding agreement or strict targets to achieve it. (v) Independent problem-solving is the convergence of policies that arise due to the mechanism by which a country has a similar response to a parallel problem, but political actors respond independently. As Benneth (1991) explains that in an independent problem-solving mechanism, the government of a country does not act on the response of other government actions, but works independently.

This study used only one among five causal mechanisms offered by Holzinger and Knill (2005), that is transnational communication. It was decided because the researchers realized that the AOE cooperation was built based on high-level communication (among the Ministers of Defense of the ASEAN member states) and the process of formation was gradual from the initiative and then 


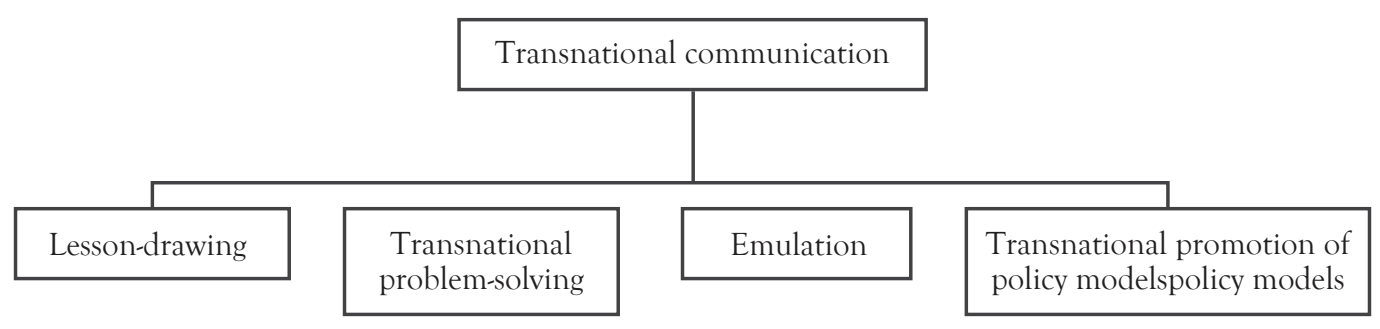

Figure 1. Causal-Mechanism in Transnational Communication as A Driver of Intergovernmental Policy Convergence (Holzinger \& Knill, 2005).

followed by all member states. Besides, the four mechanisms below represent all causal factors offered previously.

\section{RESEARCH METHOD}

Regarding the case study described above, the analysis of the OEI case within the study also employed a qualitative method. As Creswell (2014) states that in qualitative research, case studies can be used in the exploration of processes, activities, and events. Furthermore, to get a holistic account, this research collected reports of perspectives, identified factors related to the situation under study, and made sketches of the big picture that emerged (Creswell, 2014). In the process, this research collected qualitative documents in the form of public records, namely government and non-government agency reports, scientific journals, scientific books, and online newspapers.

As this case study is a single unit that identified cause-effect relationships (a pathway from $\mathrm{X}$ to $\mathrm{Y}$ ), concepts and theories were used to comprehend the implications of causation and provide an argument (pattern matching) which also involved several samples of similar cases both in the previous period in the same location (ASEAN) and the last period in different areas. It was done as an implication of the researchers' inability to directly collect data in the field. Thus, to explore the motives related to the formation of the AOE, this research required several case studies to get a comprehensive case analysis.

\section{RESULT AND ANALYSIS}

\section{COUNTERTERRORISM IN ASEAN IN THE MIDDLE OF POLITICAL STABILITY, SECURITY, AND ECONOMIC COMPOSITION}

In the realist/neorealist approach, regional cooperation is always seen as related to the presence of external power from outside the region that forms new cooperation trends and patterns in an area. At present, in addition to the particular urgency in overcoming terrorism, Southeast Asia is becoming a practice for enormous powers countries such as China and the United States to compete in strengthening their roles. It is actually utilized by each AMS that in the political, security, and economic aspects, each country competes in taking advantage of the two major powers above. For instance, the current trends in Southeast Asia region in Dong terms (2015) "looking to China for profit, the U.S. for security," this statement gives a sign that in the 21st Century the presence of Chinese economic domination amidst the trend of economic slowdown around the world encourages the search for financial benefit orientation to China for almost AMS, while in other cases those countries simultaneously have concerns over security risks due to the emergence of Chinese domination in the South China Sea (SCS) so that they cooperate in strengthening the military-strategic with the US. ${ }^{5}$

Regardless of the current trends above, generally there are four patterns of security cooperation in Southeast Asia; are (i) multilateral defense cooperation between external powers and ASEAN member states, (ii) security cooperation involving US in defense and trilateral security cooperation and strategic cooperation with countries in the Asia Pacific region, (iii) cooperation with 
China in an effort to ASEAN multilateral security cooperation with the East Asia in which the main focus is on non-traditional security issues, and (iv) security cooperation within an ASEAN framework that promotes multilateral security cooperation both among its member states and dialogue partners, as well as among members of the ASEAN Regional Forum (ASPI, 2010). From given patterns of security cooperation above, combating terrorism is one of the urgent issues related to transnational crime in non-traditional aspects which has been discussed in various high-level negotiation mechanisms among the AMS, as well as between ASEAN and several dialogue partner countries. However, why do the ASEAN member states have not been able to deal with cross-border terrorism until present time effectively?

Since 1967, the ASEAN regional security cooperation related to the issue of transnational crime has been held by four central agencies called The ASEAN Ministerial
Meeting on Transnational Crime (AMMTC), The ASEAN Chiefs of National Police (ASEANAPOL), The ASEAN Senior Officials on Drugs Matters, and The ASEAN Finance Ministers Meeting (ASPI, 2010). Among the four agencies, terrorism has already been handled by the ASEANAPOL and discussed in various ASEAN high-level negotiating agendas. Till the present time, the issue of non-traditional war and handling of terrorism as part of the cross-border problem is taken over by the ASEAN Defense Ministers (see table 1). Regarding the initial agreement on the establishment of the ASEAN Community in 2015, ASEAN formed three main pillars termed the ASEAN Political-Security Community, the ASEAN Economic Community, and the ASEAN Socio-Cultural Community. At present, terrorism issues are approved in the ASEAN Convention on Combating Terrorism (ASEAN Convention on Counter-Terrorism/ACT).

Table 1. Timeline on The Issue of Combating Terrorism in ASEAN.

\begin{tabular}{|c|c|c|c|}
\hline $\begin{array}{l}\text { Agency and } \\
\text { Negotiation }\end{array}$ & Agenda & Focus Related Issue & Explanation \\
\hline $\begin{array}{l}\text { ASEAN Ministers of } \\
\text { Interior/Home Affairs } \\
(1990 \text {-1997) }\end{array}$ & $\begin{array}{l}\text { Expanding other } \\
\text { issues related to } \\
\text { transnational crime }\end{array}$ & $\begin{array}{l}\text { Terrorism, human trafficking, } \\
\text { piracy, money laundering, and } \\
\text { cybercrime }\end{array}$ & $\begin{array}{l}\text { Emphasis on } \\
\text { information exchange } \\
\text { and policy }\end{array}$ \\
\hline $\begin{array}{l}\text { 7th ASEAN Summit, } \\
\text { the Declaration on } \\
\text { Joint Action to } \\
\text { Counter Terrorism } \\
(2001)\end{array}$ & $\begin{array}{l}\text { ASEAN leaders } \\
\text { prevent and suppress } \\
\text { all forms of terrorist } \\
\text { acts adapted to the } \\
\text { UN Charter and } \\
\text { other international } \\
\text { laws }\end{array}$ & $\begin{array}{l}\text { - Strengthening national } \\
\text { terrorism control } \\
\text { mechanisms } \\
\text { - Ratification of all } \\
\text { anti-terrorism conventions, } \\
\text { including international } \\
\text { conventions that emphasize } \\
\text { funding terrorism } \\
\text { - Increasing exchange of } \\
\text { intelligence information, } \\
\text { coordination with AMMTC } \\
\text { and other relevant ASEAN } \\
\text { agencies } \\
\text { - Developing the regional } \\
\text { capacity to enhance the } \\
\text { existing capabilities of } \\
\text { ASEAN member states to } \\
\text { investigate, detect, monitor, } \\
\text { and report terrorist acts }\end{array}$ & \\
\hline $\begin{array}{l}\text { The AMMTC Work } \\
\text { Programme \& the 8th } \\
\text { ASEAN Summit in } \\
\text { response to the } \\
\text { terrorist outrage in } \\
\text { Bali (2002) }\end{array}$ & $\begin{array}{l}\text { Combating seven } \\
\text { transnational crimes, } \\
\text { namely: drug } \\
\text { trafficking, human } \\
\text { trafficking, piracy, } \\
\text { weapons smuggling, } \\
\text { money laundering, }\end{array}$ & $\begin{array}{l}\text { Similar to the focus the } 7 \text { th } \\
\text { ASEAN Summit, the } \\
\text { Declaration on Joint Action to } \\
\text { Counter Terrorism (2001) had } \\
\text { six additional program areas: } \\
\text { information exchange, legal } \\
\text { cooperation, law enforcement }\end{array}$ & $\begin{array}{l}\text { Emphasis on } \\
\text { information exchange } \\
\text { and policy } \\
\text { coordination }\end{array}$ \\
\hline
\end{tabular}


terrorism, and cybercrime.

The ASEAN Regional
Forum Statement on
Measures Against
Terrorist Financing
$9^{\text {th }}$ ministerial
meeting (2003)

\begin{tabular}{|c|c|}
\hline $\begin{array}{l}\text { ASEAN } \\
\text { Convention on } \\
\text { Counter-Terrorism at } \\
\text { its } 12 \text { th Summit } \\
(2006)\end{array}$ & $\begin{array}{l}\text { Each ASEAN } \\
\text { member state seeks a } \\
\text { domestic ratification } \\
\text { process }\end{array}$ \\
\hline $\begin{array}{l}11^{\text {th }} \text { ASEAN Defence } \\
\text { Minister's Meeting } \\
\text { (2017) }\end{array}$ & $\begin{array}{l}\text { Joint Statement of } \\
\text { Special ADMM on } \\
\text { Countering violent } \\
\text { extremism (CVE), } \\
\text { Radicalization, and } \\
\text { Terrorism. }\end{array}$ \\
\hline $\begin{array}{l}12^{\text {th }} \text { ASEAN Defence } \\
\text { Minister's Meeting } \\
\text { (2018) }\end{array}$ & $\begin{array}{l}\text { Joint Declaration of } \\
\text { the ASEAN Ministers } \\
\text { of Defence on } \\
\text { Strengthening } \\
\text { Cooperation and } \\
\text { Building Resilience }\end{array}$ \\
\hline
\end{tabular}

The establishment of the Inter-Sessional Meeting on

Counter-Terrorism and Transnational Crimes (ISM-CT/TC) aims to stop the flow of money to terrorist groups

Note. Data is the Author's work collected from the ASEAN website. Retrieved from https://admm.asean.org/.

The table above shows that in the framework of regional cooperation in ASEAN, for more than two decades, ASEAN, as a local organization that facilitates its member states to collaborate in combating terrorism has been ineffective. It can be identified in the similarity of focus and programs carried out from one to the next negotiations. For example, in the 1990s-1997, 2001, 2002, 2003, and 2018, negotiations carried out in different agencies and various mechanisms had repeatedly discussed the exchange of intelligence information in combating terrorism. Besides, the security, political, and economic dynamics of the ASEAN region over the above period were dynamic and competitive. For instance, after Southeast Asia experienced the monetary crisis of 1997-1998 and several member states had to undergo improvements in their domestic economic and political fundamentals. cooperation, institutional capacity building, training, and extra-regional cooperation

Suspension of terrorist assets, application of international standards aimed at limiting misuse of the financial system, information exchange, and technical assistance

The signing of mutual legal assistance agreements in criminal matters

Strengthening cooperation on combating terrorism among member states and external exchanging "best practices," joint exercises, exploring new formulas in collaboration to build ASEAN capabilities to counter-terrorism partners through algologist,

\author{
After the assault case \\ by a Maute group in \\ the city of Marawi,
}

Furthermore, some issues on politics, global, and domestic terrorism in several member states became crucial. It indicates that in addition to the absence of collective will related to counter-terrorism, the condition of ASEAN member states which were undergoing a period of improvement in their domestic economic and political fundamentals was a significant factor causing the ineffectiveness of regional cooperation in combating terrorism. Hence it illustrated that the incapability of the ASEAN states.

Entering the 21st century, the pattern of relations among countries in Southeast Asia has become more competitive both in terms of the development of defense and economic forces. In the economic aspect, it occurs due to the flow of goods world trades in which $70 \%$ of them take place in the Asia Pacific (Coordinating Minister for Maritime Affairs, Republic of Indonesia, 
2017). In the geo-economic aspect, these changes place Southeast Asia as a strategic area. Each ASEAN member state competes in developing its domestic economy. However, there is a constraint from each of them in sustaining the pace of the local economy that is the loan of funds as initial capital to drive the wheels of the economy. Besides, loan funds from the International Monetary Fund (IMF) or the World Bank currently require many lengthy requirements that must be approved. Therefore, during the Chinese plan in the One Belt, One One Road (OBOR) program, which has a 21st Maritime Silk road agenda, they began promoting economic integration with China. Thus, China formed a fund lending container to support economic development in each region through the Asian Infrastructure Investment Bank (AIIB) in 2013.

The consequence of the above condition is that each country must ensure that the movement of the economy runs smoothly by strengthening defense and security. Also, amid China's presence in sustaining economic capital in Southeast Asia, countries in the region face Chinese threats in the case of the South China Sea claim. It causes a security dilemma that they increase their military strength (see table 2), and several of them decide to engage in military cooperation with their traditional partners, the United States. To take as an example of Indonesia in its foreign policy which is as a World Maritime Axis and synergistic with China's plans, Indonesia continues to hold intense military cooperation with the US (see figure 2). It caused many them, such as Gindarsah (2015), to see that Indonesia is practicing a hedging pattern. with the US (see figure 2). It caused many them, such as Gindarsah (2015), to see that Indonesia is practicing a hedging pattern.

Based on the table above, the military expenditure of funds in the form of billion US dollar in Southeast Asia in the last five years is occupied by the big five countries namely Singapore, Indonesia, Thailand, Malaysia and Vietnam (more than 4000 Million USD). Meanwhile, other countries such as Brunei Darussalam, the Philippines, Myanmar, Laos, and Cambodia spent no more than 4000 Million USD. It is directly proportional to the economic growth achievements of member states
Table 2. Military Expenditure in USD Million.

\begin{tabular}{lccccc}
\hline $\begin{array}{l}\text { 10 ASEAN Member } \\
\text { States }\end{array}$ & 2014 & 2015 & 2016 & 2017 & 2018 \\
\hline Indonesia & 7032 & 8225 & 7620 & 8178 & 7661 \\
Brunei Darussalam & 479 & 417 & 402 & 347 & 336 \\
Philippines & 2866 & 3136 & 4223 & 3755 & 3753 \\
Malaysia & 4035 & 4344 & 4159 & 3495 & 3208 \\
Myanmar & 3290 & 3818 & 3651 & 3464 & 3155 \\
Laos & - & - & - & - & \\
Cambodia & 479 & 346 & 394 & 464 & 525 \\
Vietnamese & 4337 & 4729 & 5089 & 5074 & 5451 \\
Singapore & 8743 & 9325 & 9915 & 10196 & 10499 \\
Thailand & 5462 & 5806 & 6131 & 6306 & 6420 \\
\hline
\end{tabular}

Note. Data retrieved from tradingeconomics.com and Stockholm International Peace Research Institute

(see table 3) that in 2018 World IMD announced that Singapore ranked third in the world as a competitive country, followed by Malaysia, Thailand, Indonesia, and the Philippines. The data reveal that both in economic and defense aspects, Singapore is the country with the highest achievements and expenditures. It is inversely proportional to other countries like Myanmar, Laos, and Cambodia, which are still lagging behind other ASEAN member states.

Based on the table above, the military expenditure of The diagram above shows that Indonesia is one of the countries in ASEAN that openly conducts strategic economic cooperation with China in which it decides to join AIIB. However, in terms of training and exercise, the US with $36 \%$ dominates the collaboration compared to the eight other partner countries. Indonesia does merely $6 \%$ of the activity with China. It does it more with the neighboring countries such as Malaysia (8\%) and Singapore (28\%) which ranks third and second after the US. It indicates that in terms of security, Indonesia tends to make the US as its best partner to compete with Chinese forces. 


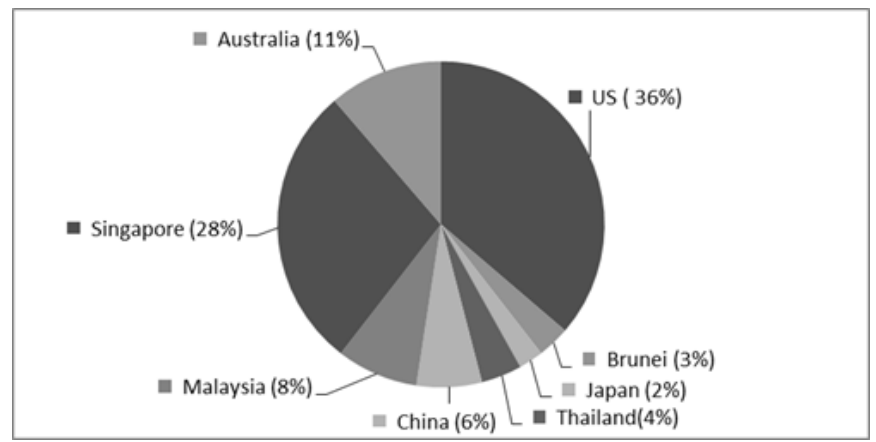

Figure 2. Top Indonesia's Partner in Training and Exercise 2009-2013 (Gindarsah, 2015).

Table 3. Regional Ranking for 2018 World IMD Competitiveness Ranking.

\begin{tabular}{cccc}
\hline $\begin{array}{c}\text { WORLD } \\
\text { RANK } \\
(2018)\end{array}$ & $\begin{array}{c}\text { WORLD } \\
\text { RANK } \\
(2017)\end{array}$ & COUNTRY & SCORE \\
\hline 3 & 3 & Singapore & 98.553 \\
22 & 24 & Malaysia & 85.174 \\
30 & 27 & Thailand & 79.45 \\
43 & 42 & Indonesia & 68.925 \\
50 & 41 & Philippines & 64.659 \\
\hline
\end{tabular}

Note. Data accessed from IMD World Competitiveness Yearbook 2018.

As for the ASEAN region, China has a role as a "primary economic patron", namely as the largest source of Foreign Direct Investment (FDI) and Official Development Assistance (ODA), especially for weak countries in ASEAN such as, Cambodia, Laos and Myanmar (Gerstl \& Strasakova, 2016). For example, in the Cambodian case in which it is politically the closest alliance of China and is a staunch supporter of China's main interests in the South China Sea claim (Gerstl \& Strasakova, 2016). For example, in the Cambodian case in which it is politically the closest alliance of China and is a staunch supporter of China's main interests in the South China Sea claim (Gerstl \& Strasakova, 2016). The most visible event was in 2012 when President Hu Jintao promised millions of dollars in aid and soft loans to Cambodia. However, the issue of the South China Sea was not discussed during the ASEAN Summit in Phnom
Penh (Gerstl \& Strasakova, 2016). The consequences of this event were apparent during the ASEAN Foreign Minister's Meeting in Phnom Penh in which they agreed on the critical elements in implementing the Code of Conduct (CoC) in solving the South China Sea case. Unfortunately, it could not be performed due to the reluctance of delegates from Cambodia.

Furthermore, a domestic politician Sam Rainsy took advantage of the South China Sea case as an internal issue by stating that the expansionist country of Vietnam, which was then the chair of ASEAN, was accused of using the opportunity to bring the case to the international sphere. Whereas in other instances, Vietnam often provoked through military training at the border that according to him, it threatened the stability and regional security of Southeast Asia. It is the first case in the last 45 years in ASEAN that no Joint Communique was decided after the negotiations and after two months they ended in a deadlock. Cambodian Prime Minister Hun Sen visited Beijing and received a soft loan and gift (Gerstl \& Strasakova, 2016).

The "ASEAN Way" which promotes national sovereignty in the highest position implicates for non-interference rules (a 'realist' appreciation of national interests) on the domestic problems of countries that limit the implementation of counter-terrorism and produce weak regional cooperation mechanisms (Jones \& Smith, 2006). Nevertheless, cooperation in combating terrorism in ASEAN is more effective through the use of a pattern of bilateral, trilateral, and multilateral cooperation rather than the negotiating mechanism facilitated by ASEAN. For example, the intelligence exchange cooperation between the Philippines and Singapore in 2002 which had implicated for the arrest of 15 terrorist suspects in Singapore in which one of them was Fathur Rahman Al-Ghozi as an Al-Qaeda bomb expert. Another example is the multilateral cooperation in the exchange of information and the establishment of communication procedures by countries such as the Philippines, Indonesia, Malaysia, Cambodia, and Thailand in 2002. This collaboration was a Philippine initiative because ASEAN was unable to concretely push the agenda of overcoming terrorism (Jones \& Smith, 2006). 
Indications of the weak role of ASEAN concretely in combating terrorism are also supported by the statement of Jones \& Smith (2006) that ASEAN intelligence agents focus only on policies of political stability within the borders of their respective countries which result in intelligence failure in paying attention to transnational threats. Explicitly, it can be seen when there is an increase in terrorist networks between the most extensive Islamic militant groups in Southeast Asia known as Jemaah Islamiyah (JI) and the penetration of Global Jihad from Al-Qaeda's global terrorist agency Osamah bin Laden (Jones \& Smith, 2006). Al-Qaeda's infiltration through related groups such as Jemahaan Islamiyah aims to replace the results of post-colonialism nation-building in the region with Islamic rules 'a Darul Islam Nusantara' (Southeast Asian Homeland) in Southern Thailand, Malaysia, Mindanao, Singapore, and the Indonesian Archipelago. According to Lee Kuan Yew, these groups spread the ideology and values of universal Jihad (Lee, 2002). Al-Qaeda plans in regional control in Southeast Asia which is divided into four areas or mantiqi for operational purposes. Specifically, Mantiqi 1 covers Malaysia, Singapore, and Southern Thailand, Mantiqi 2 includes most of Indonesia, Mantiqi 3 consists of East Malaysia and Indonesia including Sulawesi, Kalimantan, Brunei, and the Southern Philippines, and Mantiqi 4 comprises Papua and Australia (Jones \& Smith, 2006: 220-221). However, the essence of all mantiqi above is that the core of the terrorism network spread begins in the Philippines and Indonesia.

In the Philippines, the early branch of the network emerged from the Moro Muslim separatism struggle in Mindanao from 1950 and escalated globally in the 1970s with the emergence of the Moro Islamic Liberation Front (MILF) and then Abu Sayaf (father of the sword) as a cruel splinter group separating themselves in 1991 (State Department, 2002). However, both the MILF and Abu Sayaf's group received support from Al-Qaeda. It was seen in 1988 that they received logistical and financial supplies from money laundering generated from non-governmental organizations of brother-in-law Osamah bin Laden, namely Mohammed Hamal Khalifa (Manila Times, 1 November 2002). In the development of terrorist networks in the Philippines, Osama bin Laden's brother-in-law's role was very significant so that later he would develop networks to Libya and Algeria (Armed Islamic Group) and provide opportunities for Abu Sayaf s personnel to study at Islamic Universities in Pakistan (Dalangi 2003). Of all these developments, in addition to getting adequate logistical supplies in training camps, the personnel received skills training to deal with ammunition routinely from the Mujahidi of Pakistan, Afghanistan, and Algeria (Hidlago, 2000).

During more or less the same period, Al-Qaeda developed a connection between Moro Philippine and Indonesia which took from radical groups such as the paramilitary organization of the Jihad command (Holy War Command) which had a central figure called Sheikh Abu Bakar Baashir. Since Baashir was arrested for allegedly having connections with the Jihad Command, in 1985, he fled to Selangor Malaysia and met Abu Jibril. In Malaysia, they built schools, hospitals, and Islamic communities in Selangor. During this period, a former Afghan fighter, Hambali, and together with Baashir, attended the mantiqi Jemaah Islamiyah (Barton, 2002). Through this momentum, the connections established began to spread to Malaysia through Yazid Sufaat, former Malaysian army officer who in the 1990s had businesses in Kuala Lumpur such as Green Laboratories and Infocus Technology (Jones \& Smith, 2002). In the same period, connections from Malaysia spread and expanded its reach to Singapore through mosques across the causeway in Johor Baru. Other figures appeared such as Mas Selamat Kastari who was in charge of overseeing Singapore relations while Ibrahim Maidin coordinated Jemaah Islamiya cells in city-states. Since the 1990s Maidin held religious classes in Singapore as well as concurrent recruitment for Jemaah Islamiyah cells (Rahim, 2003). After the fall of the Soeharto regime, at the end of 1998 Baashir, Hambali, and Abu Jibril returned from Malaysia to Solo and Jakarta and established the Indonesian Council of Indonesian Mujahideen (Council of Indonesian Islamic Fighters). Through this organization they encouraged connections among radical Islamists in Indonesia, the Philippines, and Singapore. The communication with Khalid Sheikh 
Mohammed who often came to the Philippines and Hambali's significant position in the Al-Qaeda Military Command Council made this network more solid.

The operation carried out by terrorism networks according to the researcher is a success, and it confirms that in addition to the failure of intelligence in each country, in fact, there are countries that should be the pioneers in tackling terrorism because they already have the capability to deal with their operations earlier. For example, Singapore in February 2003 through the Internal Security Department (ISD) found e-mails and letters relating to activities carried out by Maidin as Jemaah Islamiyah leaders with Mullah Omar, Mohammed Atta, and Osamah bin Laden in Kabul (Rahim, 2003). The e-mails and contacts aimed at damaging bilateral relations between Singapore and Malaysia, creating conflict between the two countries and further disrupting regional stability ('Sweeping Asian Terror Alliance Uncovered', 2002; 'Opening Remarks by Prime Minister Goh Chok Tong', 2002) in Jones \& Smith (2006). Even in the statement of Nathan (2002) that according to Singapore investigators, Jemaah Islamiyah members had infiltrated Singapore during 1993. On the word of official news reports, the Singapore authorities argued that they had handled the problem from the start and had analyzed it without the assistance of the US (Star, 2002). However, it raises a question that if local intelligence knows the problem, why have regional governments did not act in previous years, given that threats that seem to have lasted a decade have emerged in ASEAN (Jones \& Smith, 2006; 2010).

What makes it interesting is when seeing the international collaboration uses bilateral cooperation with actors outside the region in tackling terrorism militant groups. In practice, it is usually done through cooperation with the US and Australia. The two countries are very concrete in assisting in terms of sharing intelligence information and practical support more directly. It was noted that from 2002 to 2005 as an example that the most useful collaboration took place between the Australian Federal Police and the Indonesian Police in investigating the Bali attacks (see Ministry of Foreign Affairs, Alexander Downer', 2002;
Bali Bombing-Australian and Indonesian Police' 2003). Meanwhile, in the Philippines, the US provided military advisors and equipment to enhance Philippine military efforts to deal with Muslim militants especially against the Abu Sayaf's group (state Department 2002) in (Jones $\&$ Smith, 2006).

In a nutshell, some factors hinder the cooperation effectiveness in combating terrorism in ASEAN. It was due to the egocentrism of AMS which were busy with their domestic affairs, causing the intelligence agencies to miss the information on the development of terrorist connections in the region in the 1998s to 2002. During this period, several ASEAN member states were in a period of recovery in economic and political fundamentals. Furthermore, in the post-attack period in Indonesia (Bali bombing), ASEAN merely focused on high-level negotiations related to ratification and international conventions related to combating terrorism without providing concrete actions related to their mitigation. Entering the 21st-century efforts associated with the agenda of the ASEAN community were carried out, and one of them emphasized defense cooperation between defense ministers in each of the states in the ASEAN Defense Minister Meeting forum.

Nevertheless, concrete initiatives were not carried out through the ASEAN frame but rather from the actors of the country itself. During this period, each state was hyper-aggressive in pushing its economic pace and defense. On the other hand, Singapore, Indonesia, Thailand, Malaysia, the Philippines, and Vietnam were in the top five positions while Cambodia, Laos, and Myanmar were lagging far behind by other countries in ASEAN. It let China enter as an alternative to the inability of member states and ASEAN in realizing the agenda of the ASEAN Economic Community. According to the researchers, regionalism in ASEAN tends to show the pattern of realist relations to recent times.

\section{CONVERGENCE FACTORS OF OUR EYES INITIATIVE POLICY}

In general, this collaboration is a cooperation at the policy level to anticipate all possible threats to the security and mutual interests of the participating countries, 
particularly those related to terrorism and radicalism. Besides, this cooperation is a mean of communication amongst the Ministers of Defense of ASEAN for the purpose of exchange of strategic information, the referred threat is a peril that is predicted to occur in one or several countries in Southeast Asia and impact on other countries (Wira, 2018). The exciting thing is that when seeing that the initial process of the $\mathrm{OE}$ cooperation agreement was not directly appeared at the high-level forum in ASEAN, but it was an initiative from one of ASEAN member states which informed informally to several other members. In the continuation of this cooperation process, it is ultimately followed by all AMS. Therefore, in identifying the policy convergence process above (see figure 3 ), in this part, the researchers applied the policy convergence theory of Holzinger and Knill (2005) which focuses on the transnational communication.

Terrorist threat in Southeast Asia develops in two different clusters, namely Al-Qaeda and Islamic State (IS). The Al-Qaeda centric began with 400 terrorist fighters in Southeast Asia who got training and experience in the war from Afghanistan and Pakistan. After returning to their home countries, they formed groups such as Jemaah Salafiyah in Thailand, Malaysian Militant Collection (KMIM) in Malaysia, Abu Sayaf Group (ASG) in the Philippines, and Jemaah Islamiyah (JI) in Singapore and Indonesia. Whereas Islamic State centric began with affiliation with groups such as the Black Crow Collection and al Kubro Generation in Malaysia, the Jamaah Ansarud Daulah in Indonesia, and the Islamic State Lanao (Maute Group) and Islamic State in the Philippines. Therefore, from this centric cluster, it was found that by the middle of 2014, approximately 63 groups in Southeast Asia had sworn allegiance to the Islamic State leader, Abu Bakar al Baghdadi (Ryacudu, 2018). After the loyalty oath in the following years there was an increase in brutal violence by shooting, beheading prisoners, burning churches, kidnapping, and using women as prisoners in Southeast Asia. In 2016 there were three (3) terrorist incidents in Central Jakarta (Indonesia), Puchong (Malaysia) and Davao City (Philippines). Although, in 2017 there were slightly decreased from 3 to 2 terrorist incidents, these incidents occurred again in Indonesia and Philippines. In 2018, the terrorist incidents remains the same as in the 2017, however it happened for the third times in Surabaya (Indonesia) and the first time in Yala (Thailand) (The ASEAN Post, 2018).

The previous discussion also indicates that the accomplishment of the terrorist threat using the ASEAN regional cooperation approach tended to be ineffective. Fort and Webber (2006) support the statement by affirming that in an issue of the local crisis in ASEAN was divided into three. First, if the changes in the face of local crisis use an organizational structural reform approach by providing local organizational capabilities, the emergence of new mechanisms will lead to slow movements. Second, if the changes in dealing with crises use the method of ASEAN cooperation with supranational institutions that are expected to build a norm and guide the country in taking action, then the prospects are not so good or at least only short-term. Third, if the approach used is cooperation on specific issues between two or more countries, then it will lead to more long-term and effective prospects.

Although Indonesia initiated this $\mathrm{OE}$, the moment was when ten Ministers of Defense of Southeast Asian countries attended the Joint Declaration on the ASEAN Defense Minister's Meeting (ADMM) forum. The ADMM Forum is a new forum formed in 2016 as a result of the adoption of the ASEAN Security Community (ASC) Plan of Action. If it is identified, it turns out that the terrorism issues were not discussed in every meeting. Documented from 2006 to 2019, the concrete and specific discussions of terrorism were only presented at conferences in 2017 and 2018 (see table 4). In 2017, terrorism was discussed as a result of the response of the Maute attack in Marawi City in the Philippine and the accumulation of numerous acts of hostage-taking of civil society or crew members from Indonesia near Philippine waters by terrorist groups. If referring to the above case, the terrorist activity does not only have implications for one state actor but also disadvantages for ASEAN member states. Therefore, terrorism is categorized as a shared threat by countries in Southeast Asia. 


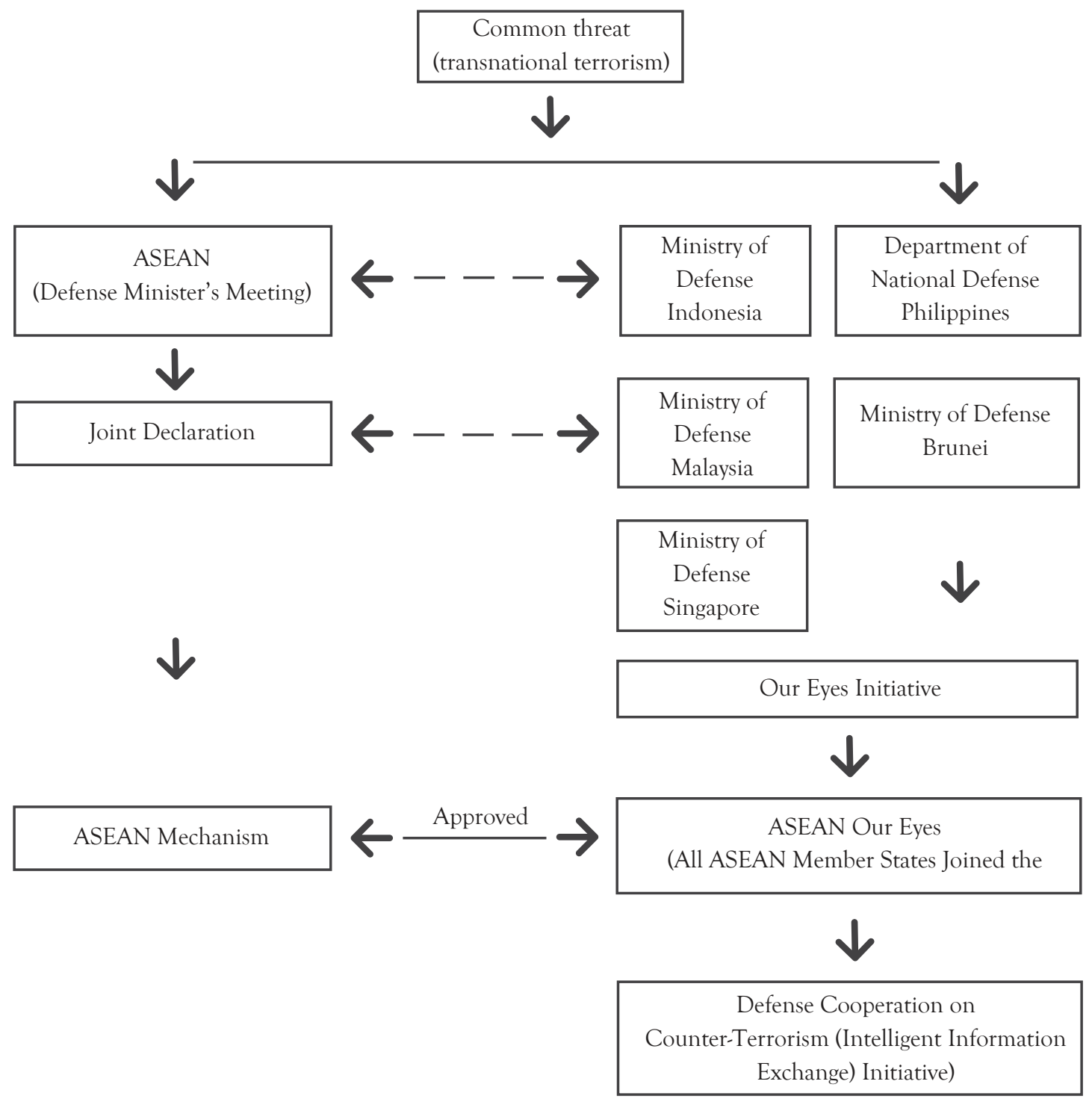

Figure 3. The Flow of Transnational Communication OUR EYES (Author's work).

The initial process of the OEI formation is interesting to be analyzed. The analysis can be carried out on two things. First, a lesson-drawing formed from the effects of countries such as Indonesia, Malaysia, the Philippines, Brunei, Thailand, and Singapore receiving the same information regarding transnational terrorist threats. Second, the lesson-drawing that Indonesia gained, which initiates the OE formation, was stated to have been inspired by the Five Eyes intelligence collaboration. In the first lesson-drawing pattern, it was noted that the six countries signed the OEI were intense as they were affected by terrorist attacks in various forms such as bomb attacks, Islamic militant attacks which were fragments of separatist movements, as well as findings of funding of cross-border terrorist networks in Southeast Asia. In the beginning, before this initiation, the Philippines, Indonesia, and Malaysia had formed a Trilateral Cooperative Arrangement (TCA) cooperation aiming to frustrate terrorist plans in piracy and hostage-taking in the Sulu Sea. This trilateral cooperation produced the first component called Trilateral Maritime Patrol (TMP) and Maritime Command Centers (MCC).

Moreover, in this trilateral collaboration, Singapore and Brunei were invited as observers. In the process, Singapore had provided an Information Fusion Center (IFC) in 


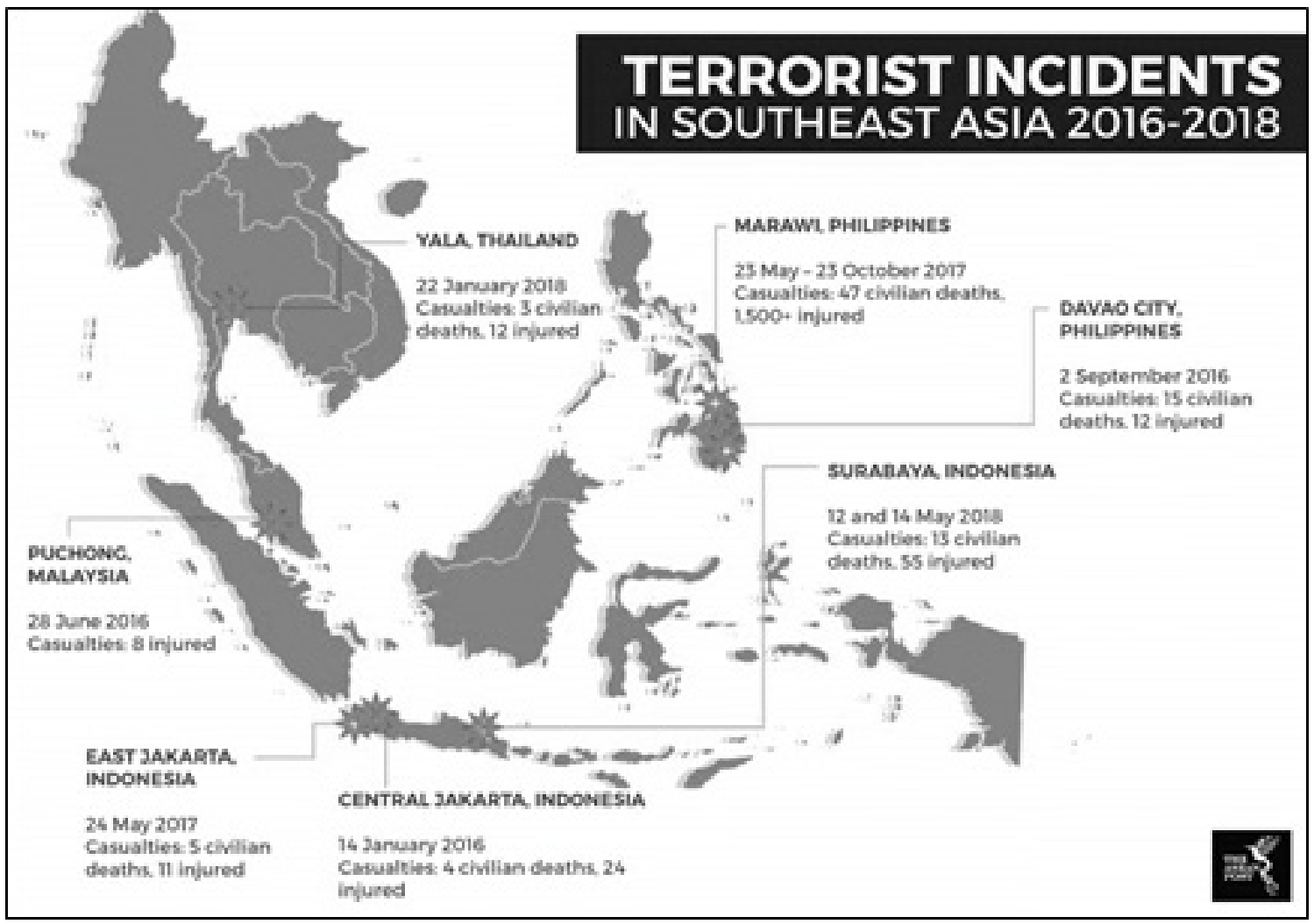

Figure 4. The Flow of Transnational Communication OUR EYES (The ASEAN Post, 2018).

facilitating maritime information for TMP. The second component of the TCA among Indonesia, Malaysia, and the Philippines was launched on October 12, 2017, in the Trilateral Air Patrol (TAP) at Subang Air Base in Malaysia. Through the pattern of lesson-drawing related to combating terrorism, the information obtained by Indonesia, Malaysia, the Philippines, Singapore, and Brunei was not much different. It was because they experienced intense terrorist attacks and also patterns of trilateral and multilateral cooperation which caused them to have the same information on dealing with terrorism. Therefore, in the OE formation, these countries tend to be convergent, primarily based on the principle of taking networks to defeat the networks. Hence, if terrorists in Indonesia, Malaysia and Singapore were able to train together in the Philippines, then Southeast Asian countries should also participate in joint exercises, training and operations (Ryacudu, 2018).
The second lesson-drawing pattern indicated that OEI was an imitation of the Five Eyes intelligence collaboration (Ryacudu, 2018; Gnanasagaran, 2018; Gunaratna, 2019; Parameswaran, 2019). Based on the analysis of the Five Eyes as the basis for lessons, it was found that the OEI formation initiated by Indonesia was inappropriate. First, in terms of the organizational structure, Five Eyes is an intelligence community while OEI was initiated by the Ministers of Defense of each state in ASEAN. Besides, in the context of combating terrorism, each state of which the intelligence agents are part of Five Eyes has counter-terrorism centers. For example, Canada has an integrated Threat Assessment Center (ITAC), USA with the National Counter-Terrorism Center (NCTC), UK runs a Joint Threat Assessment Center (JTAC), Australia possesses a National Threat Assessment Center (NTAC), and New Zeeland owns a Combined Threat Assessment Center (CTAG) (Cox, 2012). Unlike the OEI case in which the leading sector related to intelligence is a military force under the control of the Minister of Defense of each member state. 
Table 4. Annual Meeting ASEAN Defense Minister's Meeting.

\begin{tabular}{|c|c|c|}
\hline $\begin{array}{l}\text { Annual } \\
\text { Meeting }\end{array}$ & Action Plan & Date \\
\hline $1^{\text {st }} \mathrm{ADMM}$ & Joint Press Release of the Inaugural ASEAN Defense Minister's Meeting. & Malaysia, May 2006 \\
\hline $2^{\text {st }} \mathrm{ADMM}$ & $\begin{array}{l}\text { Joint Declaration of the ASEAN Defense Ministers on Enhancing } \\
\text { Regional Peace and Stability. }\end{array}$ & $\begin{array}{l}\text { Singapore, } \\
\text { November } 2007\end{array}$ \\
\hline $3^{\text {st }} \mathrm{ADMM}$ & $\begin{array}{l}\text { Joint Declaration of ASEAN Defense Ministers on Strengthening } \\
\text { ASEAN Defense Establishments to Meet the Challengers of }\end{array}$ & $\begin{array}{l}\text { Thailand, } \\
\text { February } 2009\end{array}$ \\
\hline $4^{\mathrm{st}} \mathrm{ADMM}$ & $\begin{array}{l}\text { Joint Declaration of the ASEAN Defense Ministers on Strengthening } \\
\text { ASEAN Defense Cooperation for Stability and Development of the } \\
\text { Region.Non-Traditional Security Threats. }\end{array}$ & Vietnam, May 2010 \\
\hline $5^{\text {st }} \mathrm{ADMM}$ & $\begin{array}{l}\text { Joint Declaration of the ASEAN Defense Ministers on Strengthening } \\
\text { Defense Cooperation of ASEAN in the Global Community to Face New } \\
\text { Challenges }\end{array}$ & Indonesia, May 2011 \\
\hline $6^{\text {st }} \mathrm{ADMM}$ & $\begin{array}{l}\text { Joint Declaration of the ASEAN Defense Ministers on Enhancing } \\
\text { ASEAN Unity for A Harmonized and Secure Community. }\end{array}$ & Cambodia, May 2012 \\
\hline $7^{\text {st }} \mathrm{ADMM}$ & $\begin{array}{l}\text { Brunei Darussalam Joint Declaration of The ASEAN Defense Ministers } \\
\text { "Securing our People, Our Future Together." }\end{array}$ & Brunei, May 2013 \\
\hline $8^{\text {st }} \mathrm{ADMM}$ & $\begin{array}{l}\text { Joint Declaration of the ASEAN Defense Ministers on Defense } \\
\text { Cooperation towards Peaceful and Prosperous ASEAN Community. }\end{array}$ & Myanmar, May 2014 \\
\hline $9^{\text {st }} \mathrm{ADMM}$ & $\begin{array}{l}\text { Joint Declaration of the ASEAN Defense Ministers on Maintaining } \\
\text { Regional Security and Stability for and by the people. }\end{array}$ & Malaysia, March 2015 \\
\hline $10^{\text {st }} \mathrm{ADMM}$ & $\begin{array}{l}\text { Joint Declaration of the ASEAN Defense Ministers on Promoting } \\
\text { Defense Cooperation for A Dynamic ASEAN Community. }\end{array}$ & Laos, May 2016 \\
\hline $11^{\text {st }} \mathrm{ADMM}$ & $\begin{array}{l}\text { Joint Statement of Special ADMM on Countering violent extremism } \\
\text { (CVE), Radicalization, and Terrorism. Condemning attack carried out } \\
\text { mainly in Southeast Asia, including the attack by the Maute Group in } \\
\text { Marawi City, Philippines, which led to casualties destruction of properties } \\
\text { and displacement of people, among others. }\end{array}$ & $\begin{array}{l}\text { Philippines, } \\
\text { October } 2017\end{array}$ \\
\hline $12^{\text {st }}$ ADMM & $\begin{array}{l}\text { Joint Declaration of the ASEAN Defense Ministers on Strengthening } \\
\text { Cooperation, Building Resilience. Deepen counter-terrorism cooperation } \\
\text { among ASEAN defense establishments, and with our external partners, } \\
\text { through dialogue, sharing of best practices, joint exercises and training, } \\
\text { and exploring new forms of collaboration, including cross-sectoral } \\
\text { cooperation, to build ASEAN capabilities in tackling the threat of } \\
\text { terrorism complementing the work of ASEAN-related frameworks and } \\
\text { mechanisms on counter-terrorism. }\end{array}$ & $\begin{array}{l}\text { Singapore, } \\
\text { October } 2018\end{array}$ \\
\hline $13^{\text {st }} \mathrm{ADMM}$ & Joint Declaration of the ASEAN Defense Ministers on Sustainable Security. & Thailand, July 2019 \\
\hline
\end{tabular}

Note. Data is the Author's work collected from the ASEAN website. Retrieved from https://admm.asean.org/.

The Five Eyes did not carry out covert operations but complemented the national intelligence capabilities of each country with broad coverage on a global scale (Dailey, 2017). So in its development, the Five Eyes Alliance invited its member states to share in the collection and analysis of information related to global threats. Precisely, the assignment was private, but there were some indications that Australia was responsible for gathering intelligence information in the South and East Asia, New Zealand covering the South Pacific and Southeast Asia, Britain in Europe and Western Russia, while the United States monitored the Caribbean, China, Russia, and the Middle East (Dailey, 2017). The challenges that would be faced by this alliance were the increase in independent terrorist organizations, international crime, and cyber-attacks. Besides, there was 
potential for friction among members of Five Eyes and its components so that they should find a balance between using methods to increase the productivity of intelligence gathering and respecting citizens' rights to privacy (Dailey, 2017). Thus, through the second lesson-drawing pattern it can be determined that Indonesia merely imitated the intelligence information exchange platform in combating terrorism.

Furthermore, the OEI cooperation is a result of the desires of countries in Southeast Asia to solve transnational terrorism problem so that each country sends its delegation through the Minister of Defense as a transnational elite network that has experiences in combating terrorism. Formally, ADMM is an elite network forum between the Ministers of Defense in ASEAN that facilitates the formation of transnational communication. However, communication occurs more tactical, especially related to combating terrorism in the informal sphere. For example, Raycudu, Indonesian Minister of Defense and Hishammuddin Husein, Malaysian Minister of Defense stated that in addition to their appreciation of the success of the Philippine government in eradicating most foreign fighters out of Marawi, they saw that the potential threat of ISIS could spread to neighboring countries to rebuild bases. Therefore, the multi-connection-lateral among the six countries will avoid this possibility (The Strait Times, 2017). As for optimizing resources and increasing the capacity to combat terrorism collectively in the region, Singapore's Minister of Defense Ng Eng Hen proposed a 3R (Resilience, Response, and Recovery) framework to guide regional efforts and cover various actions that could be taken by the state. Combating terrorism requires a shared, committed, and holistic response. It is what Dri Mohamad Maliki Bin Osman, the Senior State Minister for Defense and Foreign Affairs, stressed. He highlighted the importance of international cooperation and intelligence information exchange and reaffirmed Singapore's commitment to combat terrorism (Nexus, 2019). It is tactically agreed that a solution to counter-terrorism in an intelligence information exchange platform will involve collaboration with intelligence agencies to obtain accurate and more comprehensive information. The concept of strategic information exchange has a one-door mechanism, which is only conveyed among the Ministers of Defense of AMS. If the Ministers of Defense approved the analysis results, then direct long-distance communication among the Ministers of Defense of other member states will use the ASEAN Direct Communication Infrastructure (ADI) which has been confirmed safe from eavesdropping and hacking (Wira, 2018).

If the process of convergence of terrorist countermeasures policies in the intelligence information exchange platform, which is seen from the emulation policy, is interpreted as an urgent matter, as explained by the researchers in the previous discussion, this is indeed proven. However, if it is seen as a policy built only due to compatibility without regarding the effectiveness of the related solutions or without going through a lengthy investigation, then this is not entirely the case for the countries signing the initial OEI cooperation. As these countries have gone through intense phases of bilateral, trilateral, and multilateral cooperation, there is a short investigation that could occur in Cambodia, Laos, and Myanmar because they may not see terrorist threats as an urgent matter.

After the six Ministers of Defense agreed with the OEI, these countries, especially Indonesia as the initiator, delivered this initiation in other forums (International policy promotion) such as in The Sixth ISS-Fullerton Forum, Sherpa Meeting in Singapore in January 28-30 2018, which at that time discussed the issue of Maritime Security Challenges Management in the Southeast Asia and was attended by 22 countries (Wira, 2018). In its journey, the OEI was utilized at the ADMM meeting in Singapore on 18 October 2018 as a part of the ADMM forum. Thus, the ten AMS agreed that the OEI agenda would be included in the ADMM agenda in the coming years. At the first Our Eyes ASEAN Working Group meeting held on 29-30 October 2018 in Jakarta, all of the $\mathrm{OE}$ participating countries agreed to use the ADI as an OE communication media as well as the integration of the 365 Online Intelligence Sharing Platform that was adopted through ASEAN Military Intelligence Meeting (AMIM) within the OE activities (see the figure 5). In the Working Group meeting series, all delegates reviewed the 


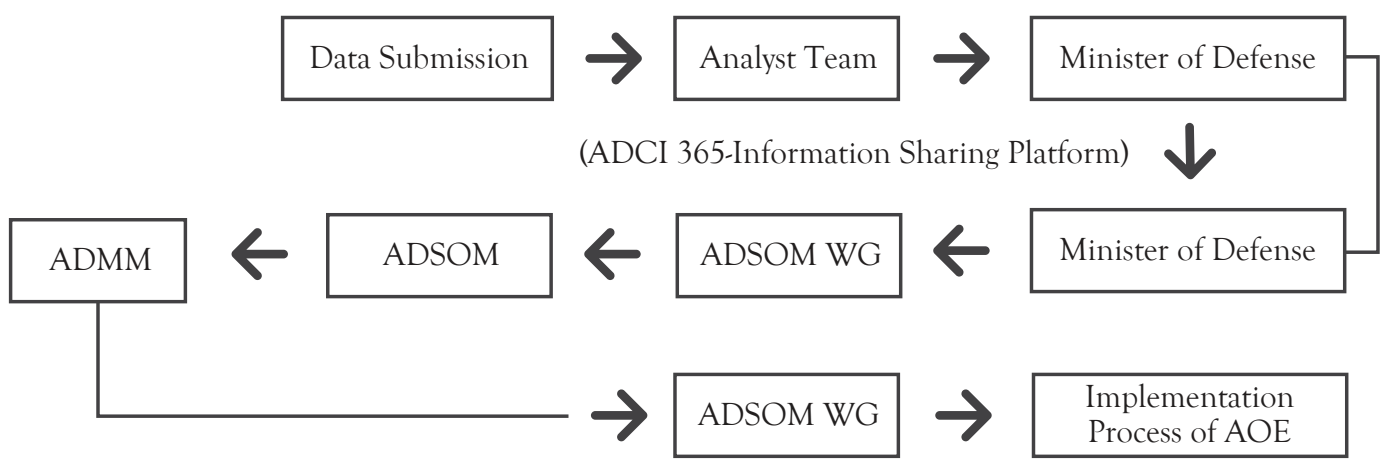

Figure 5. The Flow Mechanism of AOE (Predason, 2017)

OE Command Center in the Indonesian Ministry of Defense which showed the readiness and seriousness of Indonesia in building the OE (Wira, 2018).

For the sake of AOE's operationalization, the creation of Standard Operating Procedures (SOP) is absolutely crucial, yet this is contained within the upcoming implementation agreement in the Terms of Reference (ToR) of AOE. ${ }^{7}$ As a result (as can be seen in the figure 5) if a member state of $\mathrm{AOE}$ requests to take an action related to the intelligence information exchange, it should drive through the following phases; the first phase is the intelligence data submission carried out by the intelligence body at AMS. The composed data will be submitted to the analyst team at the Ministry of Defence of AMS. The second phase, analyst team conducts a comprehensive filter and research from gained data received from the intelligence board, and if the related data is accurate, it will be submitted to Minister of Defence in order to be approved after several considerations. The third phase; the Minister of Defence conducts direct communication amongst the AMS Defense Minister via ADCI 365-Information Sharing Platform related to the data that has been obtained from the previous stage. ${ }^{8}$

The fourth phase; as an agreement amongst AMS Defence Ministers, the implementation of guidelines regarding $\mathrm{AOE}$ was informed to ADSOM WG. As explained by Predason (2017) that the ADSOM WG was designed to support and merge the ADMM program, the ideas that AMS propose must be brought to the working level at first. In this level, the ideas are filtered, discussed, and processed until a mutual agreement is reached so that it could be continued to the next step. Basically, the composition of ADSOM WG is officially occupied by a number of Brigadier or Director, or in another case, second echelon of the Ministry of Defence as head of the delegation (Predason, 2017). The fifth phase; the ideas related to the implementation of the AOE which had been promoted earlier were submitted to ADSOM that the discussion in terms of issue or idea were directed by the Secretary General of the Ministry of Defence. In the sixth phase, ADSOM selects the ideas to be discussed as conference material at the ADMM level. The final phase, after an agreement at the ADMM level, the implementation of decisions that have been taken at the ministerial meeting are entirely implemented by the participants in ADSOM WG level (Predason, 2017). second echelon of the Ministry of Defence as head of the delegation (Predason, 2017). The fifth phase; the ideas related to the implementation of the AOE which had been promoted earlier were submitted to ADSOM that the discussion in terms of issue or idea were directed by the Secretary General of the Ministry of Defence. In the sixth phase, ADSOM selects the ideas to be discussed as conference material at the ADMM level. The final phase, after an agreement at the ADMM level, the implementation of decisions that have been taken at the ministerial meeting are entirely implemented by the participants in ADSOM WG level (Predason, 2017). 


\section{CONCLUSION}

This This study concludes that cooperation in combating terrorists in ASEAN to present times will continue to be coloured by the realist/neorealist paradigm in a regional integration frame. Each member state still has its egocentrism in terms of economic, political aspects, and enhancing the security and defense of its territory. Coupled with the presence of the two great powers (US and China) in the region has made the member states seek benefits in both the economy and security with different approaches so that it also affects the joint decision mechanism among countries in ASEAN. The policy convergence in Our Eyes Initiative (OEI) is not caused by the influence of ASEAN regional organizations, but rather by a common threat by the state, that is transnational terrorism to countries such as Indonesia, Malaysia, the Philippines, Singapore, Thailand, Singapore, and Brunei. Hence, they informally carry out transnational communication mechanism.

This study argues that the OE-related analysis can be explained by the conditions offered in Holzinger and Knill's theories. First, concrete lesson-drawing was obtained as long as countries such as Indonesia, Malaysia, the Philippines, Thailand, Singapore, and Brunei entered into bilateral, trilateral, and multilateral cooperation in combating terrorism and it was not a lesson-drawing from the collaboration of the Five Eyes intelligence group alliance. Secondly, the OE was formed as a result of a common perception in finding solutions to counter-terrorism in the region between the elite Minister of Defense networks of each ASEAN member state. Third, the OE was formed due to the urgency of solving common problems related to the handling of transnational terrorism based on lengthy analysis and investigation which was an accumulation of previous terrorist events, especially for the countries signing the preliminary initiation. Fourth, the transformation of the OEI into OE ASEAN is a result of continuity of promotion on an international scale carried out by the first signatory countries in international forums outside the ASEAN so that all ASEAN member states converge their counter-terrorism policies in the intelligence information exchange platform.
However, this study also managed to find weaknesses in the theory offered by Holzinger and Knill, especially in seeing the cause and effect of international law such as conventions and charter as aspects that might influence regional policies. Besides, in the context of transnational communication lesson-drawing, Holzinger and Knill did not explain explicitly whether the lessons learned in the convergence of the system were carried out by one country or several countries in a regional framework, or whether the lessons from the past in a local cooperation frame is the same or different. These findings open up opportunities for further study other than that policy convergence must be discussed in elements of international law, a detailed explanation of the causal policy convergence must be distinguished in the analysis unit clusters and their period.

\section{ENDNOTE}

1 In the study of regionalism, the liberal/neoliberal approach sees the state as "state-centric" and recognizes the condition of anarchy in the international arena. However, this approach sees that international organizations have the prospect of creating effective long-term cooperation in improving the worst aspects of anarchic conditions into the structure and structure of wider international relations (Wunderlich, 2007).

2 The realist/neorealist approach has similarities with the liberal/neo liberal approach in seeing the state as the center of attention and the condition of anarchy in the international arena. However, this approach is more pessimistic in seeing an efficiency of long-term international cooperation, because basically the structure of anarchy in the international arena is competitive and lacks trust, which leads to misinterpretation and misunderstanding among countries which results in a security dilemma. According to Wunderlich (2007) preventing the misbehavior in the regulatory mechanism should be done to eliminate the factors that hinder the efficiency of long-term international cooperation.

3 In the Performance Information Matrix of the Ministry of Foreign Affairs of the Republic of Indonesia II-2017 it was reported that in the ASEAN Defense Ministers Meeting-Plus Experts' Working Group on Maritime Security in Singapore, Indonesia delivered an initiative regarding "Our Eyes" cooperation related to sharing intelligence information.

4 Five Eyes is a coalition of affiliated independent intelligence agencies in which there are five oversight arrangements from the United State's National Security Agency (NSA), the United Kingdom's Government Communication Headquarters (GCHQ) the Australian Signals Directorate (ASD), Canada's Communication Security Establishment (ASD) CSEC), and New Zealand's Government Communications Security Bureau (GSCB).

5 In the Performance Information Matrix of the Ministry of Foreign Affairs of the Republic of Indonesia II-2017 it was reported that in the ASEAN Defense Ministers Meeting-Plus Experts' Working Group on Maritime Security in Singapore, Indonesia delivered an initiative regarding "Our Eyes" cooperation related to sharing intelligence information. 
6 Five Eyes is a coalition of affiliated independent intelligence agencies in which there are five oversight arrangements from the United State's National Security Agency (NSA), the United Kingdom's Government Communication Headquarters (GCHQ), the Australian Signals Directorate (ASD), Canada's Communication Security Establishment (ASD) CSEC), and New Zealand's Government Communications Security Bureau (GSCB).

7 The ToR of AOE aims to describe one of the operational mechanisms related to the platform of strategic information exchange in the areas of violent extremism, radicalization, and terrorism. This ToR was discussed at the 13th ADMM in 11 July 2019 and it will be followed up again in a related body called the ASEAN Defence Senior Official's Meeting Working Group (ADSOM WG) to be later considered by the ASEAN Defence Senior Official's Meeting (ADSOM) so that the ADMM adopts the ToR. During this on going process AMS agreed that the establishment of the AOE SOP wold be carried out within 12 months after the ToR adopted by the ADMM. Therefore, during this time period, the AOE mechanism is currently still using the existing infrastructure facilities.

8 Basically, the ADCl-365 Platform is used as a need to deal with matters related to maritime security that require timely communication and decision-making amongst ASEAN Defence Minsiters so they are capable of handling crises or emergency situations, this is discussed in the Guidelines fo Maritime Interaction in the ADMM forum. However, the platform also temporarily facilitates the AEO mechanism while awaiting the establishment of a special infrastructure security protocol for AOE.

\section{REFERENCE}

Acharya, A., \& Stubbs, R. (2006). Theorizing Southeast Asian relations: an introduction. The Pacific Review, 19(2), 125-134. doi:10.1080/09512740500473106

Allard, T. (2018, January 25). Southeast Asian states launch intelligence pact to counter Islamist threat. Reuters. Retrieved January 11, 2019, from https://www.reuters.com /article/us-asia-intelligence/southeast-asian-states-launch -intelligence-pact-to-counter-islamist-threat-idUSK BN1FE163

ASEAN. (2006). Joint Press Release of the Inagural ASEAN Defence Ministers's Meeting Kuala Lumpur. ASEAN. Retrieved March 23, 2019, from https://admm.asean.org/dmdocu ments/1.\%20Joint\%20Press\%20Release\%20of\%20the\%20 Inaugural\%20ASEAN\%20Defence\%20Ministers.pdf

ASEAN. (2007). Joint Declaration of the ASEAN Defence Ministers on Enhancing Regional Peace and Stability. ASEAN. Retrieved March 21, 2019, from https://admm.asean.org/d mdocuments/2.\%20Joint\%20Declara tion\%20of\%20the\%20ASEAN\%20Defence\%20Minis ters\%20on\%20Enhancing\%20Regiona $1 \% 20$ Peace\%20and\%20Stability.pdf

ASEAN. (2009). Joint Declaration of the ASEAN Defence Ministers on Strengthening ASEAN Defence Establishments to meet the Challenges of Non-Traditional Security Threats. ASEAN. Retrieved March 21, 2019, from https://admm.asean.org/d mdocuments/3.\%20Joint\%20Declaration\%20of\%20ASE AN\%20Defence\%20Ministers\%20on\%20Strengthen ing $\% 20$ ASEAN\%20Defence\%20Establish ments $\% 20$ to $\% 20$ Meet $\% 20$ the\%20Challeng es\%20of\%20NTS\%20Threats.pdf
ASEAN. (2010). Joint Declaration of the ASEAN Defence Ministers on Strengthening ASEAN Defence Cooperation for Stability and Development of the Region. ASEAN. Retrieved March 21, 2019, from https://admm.asean.org/dmdocu ments/4.\%20ANNEX\%2010\%20JOINT\%20DECLARA TION\%20ADMM-4.pdf

ASEAN. (2011). Joint Declaration of the ASEAN Defence Ministers on Strengthening Defence Cooperation of ASEAN in The Global Community to Face New Challenges. ASEAN. Retrieved March 23, 2019, from https://admm.asean.org/d mdocuments/5.\%20-ANNEX\%2011-\%20Joint\%20Declara tion\%20\%20the\%20Fifth\%20ADMM.pdf

ASEAN. (2013). Brunei Darussalam Joint Declaration of The ASEAN Defence Ministers: Securing Our People, Our Future Together. ASEAN. Retrieved January 10, 2020, from https://admm.asean.org/dmdocuments/Joint-Declara tion-ADMM-2013-5.\%20Brunei\%20Darussalam\%20 Joint\%20Declaration\%20of\%20the\%20ASEAN\%20De fence $\% 20 \% 20$ Ministers $\% 20-\% 2022$ Secur ing\%200ur\%20People,\%200ur\%20Future\%20Togeth er22.pdf

ASEAN. (2014). Joint Declaration of the ASEAN Defence Ministers on Defence Cooperation Towards Peaceful and Prosperous ASEAN Community. ASEAN. Retrieved from https://admm.asean.org/dmdocuments/Complete\%20 signed\%208th\%20ADMM\%20JD,\%20as\%20of\%2019No vember2014.pdf

ASEAN. (2015). Joint Declaration of the ASEAN Defence Ministers on Maintaining Regional Security and Stability for and By the People. ASEAN. Retrieved December 28, 2018, from https://admm.asean.org/dmdocuments/Joint\%20Declara tion\%20of\%20the\%209th\%20ADMM.pdf

ASEAN. (2018). Joint Declaration of the ASEAN Defence Ministers on Strengthening Cooperation Building Resilience. AESAN. Retrieved from https://admm.asean.org/dmdocu ments/2018_Oct_12th\%20ADMM_singa pore,\%2019\%20October\%202018_Final\%2012th\%20ADM M\%20JD.pdf

ASEAN. (2019). Joint Declaration of the ASEAN Defence Ministers on Sustainable Security. ASEAN. Retrieved August 1, 2019, from https://admm. asean.org/dmdocuments/2019_Ju ly_13th\%20ADMM_Bangkok,\%2011\%20Ju ly\%202019_8.\%20Final\%20ADMM\%20JD\%20Ju ly\%2019.pdf

Azalia, D. (2017). Pengaruh institusi regional terhadap konvergensi kebijakan antarnegara: studi kasus ASEAN Open Skies. Jurnal Politik, 2(2), 307-336. doi: 10.7454/jp.v2i2.120

Benneth, C. J. (1991). What is policy convergence and what causes it?. British Journal of Political Science, 21(2), 215-233. doi: $10.1017 /$ S0007123400006116

Concept Paper on The Expansion of The ASEAN Direct Commucations Infrastructure in The ASEAN Defence Minister's Meeting (ADMM) Process to The Plus Countries. (2019, July 11). Retrieved March 23, 2019, from https://admm.asean.org/.

Concept Paper on Guidelines for The Assessment of The ADMM Initiatives. (2019, July 11). Retrieved January 11, 2019, from https://admm.asean.org/.

Cox, J. (2012, December 18). Canada and the five eyes intelligence 
community. Strategic Studies Working Group Papers. Canadian Defense and Foreign Affairs Institute and Canadian International Council. Retrieved March 23, 2019, from https://www.opencanada.org/features/cana da-and-the-five-eyes-intelligence-community/

Creswell, J. W. (2004). Fourth edition research design: qualitative, quantitative, and mixed methods approaches. London: SAGE Publications

Dailey, J. (2017). The intelligence club: A comparative look at five eyes. Journal of Political Sciences and Public Affairs, 5(2), 1-9. doi: 10.4172/2332-0761.1000261

Dong, W. (2015). Hedging in International Relations: The Cases of Asia Pacific States. Peking University.

ort, B., \& Webber, D. (2006). Regional Integration in East Asia and Europe Convergence or Divergence?. USA: Routledge.

Gerring, J. (2007). Case study research: Principles and Practices. Cambridge University Press.

Gerstl, A., \& Strašáková, M. (Eds.). (2016). Unresolved Border, Land and Maritime Disputes in Southeast Asia: Bi-and Multilateral Conflict Resolution Approaches and ASEAN's Centrality. Brill.

Gindarsah, I. (2015). Indonesia's defence diplomacy: harnessing the hedging strategy against regional uncertainities. S Rajaratnam School of International Studies Singapore.

Gnanasagaran, A. (2018). Our Eyes' to combat terrorism. Retrieved March 21, 2019, from The ASEAN Post: https://theasean post.com/article/our-eyes-combat-terrorism

Gunaratna, R. (2018). ASEAN's greatest counter-terrorisme challenge: the shift from "Need to Know" to smart to share. In C. Echle, R. Gunaratna, P. Ruep, \& M. Sarmah (Eds.), Combatting Violent Extremism and Terrorism in Asia and Europe from Cooperation to Collaboration (pp. 111-128). Nanyang Technological University: Konrad-Adenauer -Stiftung Ltd and International Centre for Political Violence and Terrorism Research.

Gunaratna, R. (2018). Counterterrorism: ASEAN militaries' growing role. RSIS Commentary. No. 042-13.

Hamilton-Hart, N. (2003). Asia's new regionalism: government capacity and cooperation in the Western Pacific. Review of International Political Economy, 10(2), 222-245. doi: 10.1080/0969229032000063216

Holzinger, K., \& Knill, C. (2005) Causes and conditions of crossnational policy convergence. Journal of European Public Policy, 12(5), 775-796. doi: 10.1080/13501760500161357

Institute for Economic \& Peace. Global terrorism index 2018: Measuring the impact of terrorism, Sydney, November 2018. Retrieved March 23, 2019, from Visionof Humanity: http://visionofhumanity.org/reports

Jenne, N. (2017). Managing territorial disputes in southeast Asia: is there more than the South China Sea?. Journal of Current Southeast Asian Affairs, 36(3), 35-61. doi: 10.1177/186810341703600302

Jones, D. M., \& Smith, M.L.R. (2006). ASEAN and East Asian international relations: Regional Delusion.: Edward Elgar Publishing.

Kim, M. H. (2011). Theorizing ASEAN integration. Asian Perspective, 35(3), 407-435.

Knill, C. (2005). Introduction: cross-national policy convergence: concepts, approaches and explanatory factors. Journal of
European Public Policy. 12(5), 764-774. doi: 10.1080/13501760500161332

Neuman, W. L. (2014). Social research methods: qualitative and quantitative approaches seventh edition. Pearson New International Edition.

Organisation for Economic Co-operation and Development. (2005). Regional Integration in the Asia Pasific, Issueas and Prospects. The Bob Hawke Prime Ministerial Centre at The University of South Australia.

Pedrason, R. (2015). ASEAN's Defence Diplomacy: The Road to Southeast Asian Defence Community? Ruprecht-KarlsUniversitat Heidelberg. Institut Fur Plitische Wissenschaft.

Republika. (2017, October 24). Our Eyes, Solusi Strategis Hadapi Kelompok Radikal di ASEAN. Retrieved December 28, 2018 from Republika: https://nasional.republika.co.id/berita/poax dk423/our-eyes-solusi-strategis-hadapi-kelom pok-radikal-di-asean

Ryacudu, R. (2018). Terrorism in southeast Asia: the need for joint counter-terrorism frameworks. Journal of The International Centre for Political Violence and Terrorism Research (CTR) 10(11).

Stein, A. A. (1990). Why Nations Cooperate: Circumstance and Choice in International Relations. USA: University Press

Stein, A. A. (2001). Realism/Neorealism. In N. J. Smelser, \& P. B. Baltes (Eds.), International Encyclopedia of the Social and Behavioral Sciences (Vol. 19, pp. 12812-12815). New York: Pergamon Press.

Stein, A. A. (2015). Realism/neorealism. The International Encyclopedia of The Social and Behavioral Sciences. doi: 10.1016/B978-0-08-097086-8.93119-2

Strategy. (2010). Southeast Asia Patterns of Security Cooperation. Australian Strategy Policy Institute.

Terms of Reference (ToR) ASEAN Our Eyes. (2019, July 11). Final. Retieved from https://admm.asean.org/.

Thayer, C. A. (2010). Southeast Asia: Patterns of Security Cooperation. Canberra: ASPI.

The Straits Times. (2017). "Indonesia proposes 'mini-Interpol' plan to boost ASEAN Counter-terrorism efforts". Retrieved December 28, 2019, from https://www.straitstimes.com/a sia/se-asia/indonesia-proposes-mini-inter pol-plan-to-boost-asean-counter-terrorism-efforts

WIRA Media Informasi Kementerian Pertahanan. (2018). Kebijakan Pertahanan Negara Tahun 2018 Januari-Februari, 70(54).

Wulolo, C. M. \& Legionosuko, T. (2019). Opportunities and Optimization of the Our Eys Initiative as the Strategy for Counter-Terrorism in ASEAN. International Journal of Law and Political Science, 13(1), 1-6. doi: 10.5281/zeno do. 3607721

Wunderlich, J.U. (2008). Regionalism, Globalisation and International Order. London: Routledge. 